\title{
動加速度環境下における姿勢推定アルゴリズムの研究
}

\author{
鈴木 智*1 田原誠*2 中 澤 大 輔*3 野 波 健 蔵*3
}

\section{Research on Attitude Estimation Algorithm under Dynamic Acceleration}

\author{
Satoshi Suzuki*1, Makoto Tawara ${ }^{* 2}$, Daisuke Nakazawa ${ }^{* 3}$ and Kenzo Nonami ${ }^{* 3}$
}

\begin{abstract}
In this paper, we propose the attitude estimation algorithm under the dynamic acceleration environment. Generally, an attitude sensor has biaxial or triaxial accelerometer in order to measure the direction of gravity. In this configration, the attitude sensor has serious error under the dynamic acceleration environment, because of the measurement error of gravity that is caused by the dynamic acceleration. When we put the attitude sensor on a movable body like an UAV (Unmanned Aerial Vehicle), this kind of error is fatal for the sensor. So, we apply the extended kalman filter algorithm to reduce the estimation error. Firstly, we derive the process model for the kalman filter which is based on quaternion kinematics. Secondly, we design the extended kalman filter by using the process model. Lastly, we show the simulation and experiment result of the estimation algorithm.
\end{abstract}

Key Words: UAV, MAV, Extended Kalman Filter, Quaternion, Fully Autonomous Control

\section{1.はじめに}

近年, 空撮や農薬散布, リモートセンシングといった様々な場 面において，それまで用いられてきた有人航空機に代わり無人航 空機が活用されることが多くなっており注目を集めている。これ らの無人航空機は総称して UAV (Unmanned Aerial Vehicle) や MAV（Micro Air Vehicle）と呼ばれ，有人航空機に比べて コストや安全性，利便性に優れているということから，将来的 には監視，点検，輸送といった様々なミッションへの応用が期 待されている。 UAV /MAV 運用の早期実現のために乗り越え るべきいくつかの技術的課題があるが，その中でも最も大きな ものとして自律制御技術の確立がある。もし，自律制御技術が 確立されていなければ, 運用はオペレー夕の無線操縦に頼るし かなく，オペレータの負担も軽微ではないためである．以上の ような理由から, UAV/MAV の自律制御に関する研究が世界 中で行われてきた[1] [2]. 本研究グループでは, 1999 年より小 型 UAV の一つである小型無人へリコプタの自律制御に関する 研究を行っており，ヘリコプタのダイナミクスを表現した線形 モデルを同定的に求め, 得られたモデルに対して最適制御理論 やロバスト制御などの各種モデルベース設計法により制御器を

原稿受付 2007 年 12 月 14 日

${ }^{* 1}$ 千葉大学大学院自然科学研究科

*2ヒロボー (株)

$* 3$ 千葉大学大学院工学研究科

${ }^{* 1}$ Graduate School of Science and Technology, Chiba University

${ }^{* 2}$ Hirobo.Co.Ltd

${ }^{* 3}$ Graduate School of Engineering, Chiba University

ロ 本論文は有用性で評価されました。
設計するという独自のアプローチによって, 我が国では初とな る重量が約 $10[\mathrm{~kg}]$ 程度の小型無人ヘリコプタの自律制御に成功 を収めている $[3] \sim[5]$. そして現在では, さらに小型な機体の自 律制御を目指している.

$\mathrm{UAV} / \mathrm{MAV}$ に限らず，一般的な航空機の制御は航法・誘導・ (姿勢) 制御という三つのフェーズから成り立っているが, 小型 機体の自律制御を考える際，この中でも航法が特に重要となる. 小型機体の場合, 搭載重量の制限から高精度で重いセンサは搭 載できないため, 複数の低精度で軽いセンサを搭載し, 補正航 法演算を実装することで高精度の航法デー夕を得ることが必要 となるためである. そのような中, 先行研究では軽量で低精度 のセンサデータから機体の姿勢・方位を推定するための MARG (Magnetic, Angular Rate and Gravity) センサを開発し [6], このセンサを用いて約 $5[\mathrm{~kg}]$ 程度の機体のホバリング制御に成 功している [7]. しかし，この MARG センサには加速度環境下 で大きな姿勢誤差を生じてしまうという問題があることが明ら かになっている，今回は，そのような姿勢誤差の低減化を目指 し, クォータニオンと拡張カルマンフィルタを用いた姿勢推定ア ルゴリズムを提案する. クォータニオンと拡張カルマンフィルタ を用いた姿勢推定アルゴリズムに関しては，過去にも研究 [8] [9] があり,また，加速度環境下で姿勢誤差を生じにくい市販のセ ンサ [10] がある. しかし， センサ [10] に関しては，そのアルゴ リズムの詳細な報告がない上に，七ンサ重量が重いため小型無 人へリコプタ等への適用は難しい. 文献 [8] に関しては, 特に加 速度環境下での使用に関する言及はなく, 移動体への適用の可 否については明らかとなっていない. 文献 [9] では, 加速度環境 下および磁気外乱下での姿勢推定の高精度化の方法について述 
Table 1 Target specification of MARG sensor

\begin{tabular}{|c|c|}
\hline Items & Specifications \\
\hline Weight & $<50[\mathrm{~g}]$ \\
\hline Power & $<3[\mathrm{~W}]$ \\
\hline Accuracy of roll, pitch (Static) & $<2[\mathrm{deg}]$ \\
\hline Accuracy of roll, pitch (Under acceleration) & $<5[\mathrm{deg}]$ \\
\hline Accuracy of heading & $<5[\mathrm{deg}]$ \\
\hline Update rate & $>50[\mathrm{~Hz}]$ \\
\hline
\end{tabular}

ベられており，実証試験によってその有効性を示している．し かし，一方で，ジャイロセンサのバイアス䛊差に関しては一定 值と仮定しているため, 温度等によってリアルタイムに変化す るバイアス誤差を有する軽量・低精度のジャイロセンサを姿勢 推定に用いることは難しいと思われ，この点で文献 $[9]$ は十分 ではないと考えられる. また, 文献 [8] [9] は共に, 高性能のコ ンピュー夕を用いて実証試験を行っていると考えられ, 提案手 法が小型マイコンで計算可能であるかは明らかではない.これ に対し, 本研究では, ジャイロバイアス誤差を導入したアルゴ リズムを提案し, 加速度環境下における高精度の姿勢・方位推 定の実現を目指す。また, 小型マイコンでの実証試験を行うこ とで装置の小型化の可能性を示す. 以上が本研究の最も特徵的 な点である.

本稿で目標とする MARG センサの仕様を Table 1 に示す. Table 1 に示されるような比較的低精度ではあるが, 非常に軽 量で小型無人ヘリコプタにも十分搭載可能なハードウェアに対 して提案アルゴリズムを実装し, 検証を行う。このような小型 軽量のセンサが実現されれば, 重量の上では小型無人へリコプ 夕に限らず一般的な航空機や移動ロボット等への応用も期待で きる、以下，第 2 章では，本稿で用いる座標系およびクォー夕 ニオンについて説明を行う. 第 3 章では, Table 1 の仕様を元 に製作した MARG センサのハードウェア諸元と従来アルゴリ ズムの問題点について述べる. 第 4 章では, 今回提案するアル ゴリズムの詳細を説明し, 第 5 章においてシミュレーション結 果および実際に製作したハードウェアに実装しての実証試験の 結果について報告を行う. 最後に第 6 章にまとめを示す.

\section{2. 座標系およびクォータニオン}

\section{1 座標系}

まず, 今回用いる座標系および各座標系上で表されるべクトル の表記方法についての定義を行う.今回用いる座標系を Fig. 1 に示す。ここで, 図中の $r$-frame は Reference frame とい い, 地上の任意の点を原点として, 磁北を $X_{r}$ 軸, 重力方向を $Z_{r}$ 軸, $X_{r} Z_{r}$ 平面の垂直方向を $Y_{r}$ 軸にとった座標系である. 続いて, $b$-frame は Body frame といい, 機体の重心を原 点として, 機体前方を $X_{b}$ 軸, 機体右方向を $Y_{b}$ 軸, 機体下方 を $Z_{b}$ 軸にとった座標系である。ここで, 三次元空間中の任意 の幾何べクトルを $\boldsymbol{r}$ としたとき, $\boldsymbol{r}$ を各座標系上の代数べク トルとして表したものをそれぞれ $\boldsymbol{r}_{\boldsymbol{r}}, \boldsymbol{r}_{\boldsymbol{b}}$ と定義する．また， $r$ - frame に対する $b$ - frame の姿勢を機体姿勢として定義 する。

2.2 クォータニオン

ここでは, 本研究において機体姿勢の表現方法として採用し

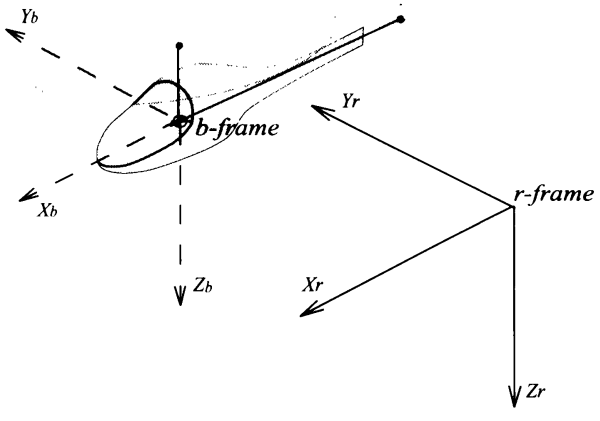

Fig. 1 Coordinate system

たクォータニオンの概要を説明する.クォータニオンとは, 1843 年にイギリスの物理・数学者 William Rowan Hamilton によっ て考案された複素数を三次元に拡張した数であり, 次式で示す ようにクォータニオン $\boldsymbol{q}$ は一つの実数部と三つの虚数部から構 成されている.

$$
\boldsymbol{q}=q_{0}+q_{1} \boldsymbol{i}+q_{2} \boldsymbol{j}+q_{3} \boldsymbol{k}
$$

ただしここで, 式中の $\boldsymbol{i}, \boldsymbol{j}, \boldsymbol{k}$ は虚数単位であり, それぞれ次 式のような関係を満たしている.

$$
\begin{gathered}
i^{2}=j^{2}=k^{2}=-1 \\
i j=k, \quad j k=i, \quad k i=j
\end{gathered}
$$

日本において，クォータニオンは四元数，またはオイラーパラ メータ [11] などと呼ばれることもあり，工学的には，物体の回 転姿勢の表現方法として用いられることが多い. 回転姿勢を表 現するクォータニオンは Simple Rotation [11] を用いて定義す ることができる，いま，才イラーの定理によれば，Fig. 1 中の $b$-frame が $r$-frame に対してどのような回転姿勢をとって いた場合でも，回転軸を表す単位べクトル $\boldsymbol{\lambda}_{r}^{b}$ とその軸周りの回 転角度 $\phi_{r}^{b}$ を用いてその回転姿勢を表現することが可能である. $\boldsymbol{\lambda}_{r}^{b}$ と $\phi_{r}^{b}$ の組を用いた回転姿勢の表現法を Simple Rotation と呼ぶ.ただしここで， $\boldsymbol{\lambda}_{r}^{b}$ は式（4）のように成分で表すこと ができ,そのノルムは 1 となる.

$$
\begin{gathered}
\boldsymbol{\lambda}_{r}^{b}=\left[\begin{array}{lll}
l & m & n
\end{array}\right]^{T} \\
\sqrt{l^{2}+m^{2}+n^{2}}=1
\end{gathered}
$$

以上のような Simple Rotation を用いて, $r$ - frame に対す る $b$ - frame の回転姿勢を表現するクォータニオン $\boldsymbol{q}_{r}^{b}$ は次式 のように定義される.

$$
\boldsymbol{q}_{r}^{b}=\left[\begin{array}{c}
\cos \left(\frac{\phi_{r}^{b}}{2}\right) \\
l \sin \left(\frac{\phi_{r}^{b}}{2}\right) \\
m \sin \left(\frac{\phi_{r}^{b}}{2}\right) \\
n \sin \left(\frac{\phi_{r}^{b}}{2}\right)
\end{array}\right]
$$

ここで, $\boldsymbol{q}_{r}^{b}$ のノルムは式（5）より常に 1 となる.

クォータニオンは, $\boldsymbol{q}=\left[\begin{array}{llll}q_{0} & q_{1} & q_{2} & q_{3}\end{array}\right]^{T}$ というように虚 数単位を省いたべクトル表記で表されることも多く,この表記 
法によってクォータニオンの和, 差, 積は次式のように定義さ れる。

$$
\begin{aligned}
\boldsymbol{q}+\boldsymbol{p} & =\left[\begin{array}{llll}
q_{0}+p_{0} & q_{1}+p_{1} & q_{2}+p_{2} & q_{3}+p_{3}
\end{array}\right]^{T} \\
\boldsymbol{q}-\boldsymbol{p} & =\left[\begin{array}{llll}
q_{0}-p_{0} & q_{1}-p_{1} & q_{2}-p_{2} & q_{3}-p_{3}
\end{array}\right]^{T} \\
\boldsymbol{q p} & =\left[\begin{array}{cccc}
q_{0} & -q_{1} & -q_{2} & -q_{3} \\
q_{1} & q_{0} & -q_{3} & q_{2} \\
q_{2} & q_{3} & q_{0} & -q_{1} \\
q_{3} & -q_{2} & q_{1} & q_{0}
\end{array}\right]\left[\begin{array}{c}
p_{0} \\
p_{1} \\
p_{2} \\
p_{3}
\end{array}\right]
\end{aligned}
$$

また, $\boldsymbol{q}$ に共役なクォータニオン $\boldsymbol{q}^{*}$ は次式のように定義される.

$$
\boldsymbol{q}^{*}=\left[\begin{array}{llll}
q_{0} & -q_{1} & -q_{2} & -q_{3}
\end{array}\right]^{T}
$$

今, $r$ - frame 上の代数ベクトル $\boldsymbol{r}_{r}$ から $b$-frame 上の 代数べクトル $\boldsymbol{r}_{b}$ への座標変換は次式で表すことができる.

$$
\left(\boldsymbol{r}_{b}\right)_{q}=\boldsymbol{q}_{r}^{b *}\left(\boldsymbol{r}_{r}\right)_{q} \boldsymbol{q}_{r}^{b}
$$

ただしここで，式中の $\left(\boldsymbol{r}_{b}\right)_{q}$ および $\left(\boldsymbol{r}_{r}\right)_{q}$ は三次元ベクトルを クォータニオン表記したものであり，それぞれ次式のように定 義される.

$$
\left(\boldsymbol{r}_{b}\right)_{q}=\left[\begin{array}{ll}
0 & \boldsymbol{r}_{b}^{T}
\end{array}\right]^{T}, \quad\left(\boldsymbol{r}_{r}\right)_{q}=\left[\begin{array}{ll}
0 & \boldsymbol{r}_{r}^{T}
\end{array}\right]^{T}
$$

\section{MARG センサ}

ここでは, 先行研究で開発された MARGセンサのハードウェ アの諸元と従来の機体姿勢推定アルゴリズムの概要およびその 問題点について述べる.

\section{1 諸元}

MARG センサの全体像を Fig. 2 に, 諸元を Table 2 に示 す.このセンサは, 3 軸の加速度センサ, ジャイロセンサ, 地磁 気センサの出力を用いて現在の姿勢を表すクォータニオンを推 定するアルゴリズムを実装した姿勢センサの一種である。姿勢 推定アルゴリズムの詳細に関しては後述する.

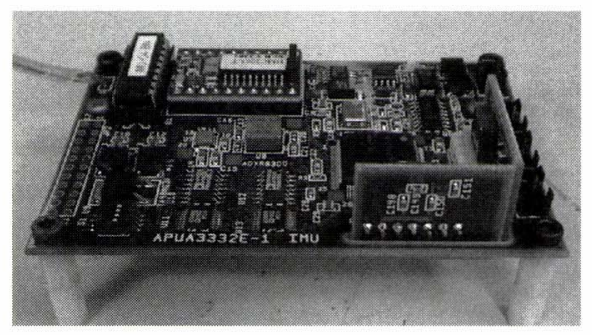

Fig. 2 Overview of MARG sensor

Table 2 Specification of MARG sensor

\begin{tabular}{|c|l|}
\hline Weight & $46[\mathrm{~g}]$ \\
$\mathrm{L} \times \mathrm{W} \times \mathrm{H}$ & $90[\mathrm{~mm}] \times 60[\mathrm{~mm}] \times 20[\mathrm{~mm}]$ \\
Angle rate sensor & $\pm 300[\mathrm{deg} / \mathrm{sec}]$ \\
Accelerometer & $\pm 3[\mathrm{G}]$ \\
Magnetometer & $2[\mathrm{gauss}]$ \\
32-bit micro-computer & $50[\mathrm{MHz}], 10$ bits A/D converter \\
\hline
\end{tabular}

\section{2 従来のアルゴリズムとその問題点}

本節では, 従来, MARG センサに実装されていた姿勢推 定アルゴリズムの概要について述べる。まず，r-frame 上 での重力ベクトルを $\boldsymbol{g}_{r}=\left[\begin{array}{lll}0 & 0 & g\end{array}\right]^{T}$, 地磁気ベクトルを $\boldsymbol{m}_{r}=\left[\begin{array}{lll}m_{n} & 0 & m_{d}\end{array}\right]^{T}$ とする.ただし, $g$ は重力加速度, $m_{n}$ は水平地磁気， $m_{d}$ は垂直地磁気をそれぞれ表している．ここ で，現在の姿勢を表すクォータニオンの推定值を $\hat{\boldsymbol{q}}_{r}^{b}$ とすると， $b-$ frame 上での重力ベクトルおよび地磁気ベクトル推定值は 次式となる。

$$
\begin{aligned}
\left(\hat{\boldsymbol{g}}_{b}\right)_{q} & =\hat{\boldsymbol{q}}_{r}^{b *}\left(\boldsymbol{g}_{r}\right)_{q} \hat{\boldsymbol{q}}_{r}^{b} \\
\left(\hat{\boldsymbol{m}}_{b}\right)_{q} & =\hat{\boldsymbol{q}}_{r}^{b *}\left(\boldsymbol{m}_{r}\right)_{q} \hat{\boldsymbol{q}}_{r}^{b}
\end{aligned}
$$

続いて，機体に搭載された加速度センサおよび磁気センサの 出力をそれぞれ $\boldsymbol{a}_{\text {measure }}=\left[\begin{array}{lll}a_{x} & a_{y} & a_{z}\end{array}\right]^{T}, \boldsymbol{m}_{\text {measure }}=$ $\left[\begin{array}{lll}m_{x} & m_{y} & m_{z}\end{array}\right]^{T}$ とすると, これらと上述した $b$ - frame 上 での重力ベクトルおよび地磁気べクトル推定值との誤差べクト ルは次式となる.

$$
\boldsymbol{\epsilon}\left(\hat{\boldsymbol{q}}_{r}^{b}\right)=\left[\begin{array}{c}
\boldsymbol{a}_{\text {measure }} \\
\boldsymbol{m}_{\text {measure }}
\end{array}\right]-\left[\begin{array}{c}
\hat{\boldsymbol{g}}_{b} \\
\hat{\boldsymbol{m}}_{b}
\end{array}\right]
$$

いま，各センサの誤差がないと仮定すれば，最も確からしい クォータニオン推定值は式（15）において $\boldsymbol{\epsilon}\left(\hat{\boldsymbol{q}}_{r}^{b}\right)=0$ とした同 次連立方程式を解くことで得られることが分かる。しかし，式 （15）は 4 個の未知変数に対して式が 6 個ある過剩条件の連立方 程式であるため一般には解くことができない. よって，最小二 乗法を用いて誤差の二乗和を最小とするような近似解を求める. Gauss-Newton 反復法を用いれば，あるステップにおいて誤差 の二乗和を最小に近づけるような修正べクトルは次式となる。

$$
\Delta \boldsymbol{q}=\left[\boldsymbol{X}^{T} \boldsymbol{X}\right]^{-1} \boldsymbol{X}^{T} \boldsymbol{\epsilon}\left(\hat{\boldsymbol{q}}_{r}^{b}\right)
$$

ただし，ここで $\boldsymbol{X}$ は以下に示すようなヤコビアンである.

$$
\begin{aligned}
\boldsymbol{X}_{i j} & =\frac{\partial\left(\boldsymbol{y}_{b}\right)_{i}}{\partial\left(\hat{\boldsymbol{q}}_{r}^{b}\right)_{j}}, \quad i=1,2 \ldots 6, \quad j=1,2 \ldots 4 \\
\boldsymbol{y}_{b} & =\left[\hat{\boldsymbol{g}}_{b}^{T}, \quad \hat{\boldsymbol{m}}_{b}^{T}\right]^{T}
\end{aligned}
$$

一方，現在の姿勢を表す真のクォータニオンを $\boldsymbol{q}_{r}^{b}$ としたと き，その時間微分と機体角速度 $\boldsymbol{\omega}_{b}$ は以下の関係であることが 知られている。

$$
\dot{\boldsymbol{q}}_{r}^{b}=\frac{1}{2} \boldsymbol{q}_{r}^{b}\left(\boldsymbol{\omega}_{b}\right)_{q}
$$

これより， $\hat{\boldsymbol{q}}_{r}^{b}$ の時間微分に関しても同様に次式のような関係が 成り立つことが分かる.

$$
\dot{\hat{\boldsymbol{q}}}_{r}^{b}=\frac{1}{2} \hat{\boldsymbol{q}}_{r}^{b}\left(\boldsymbol{\omega}_{b}\right)_{q}
$$

式（16）と式（20）を次式のように組み合わせることによって, クォータニオン推定值を得るというのが従来のアルゴリズムで ある、ただしここで， $k$ はスカラゲインである

$$
\dot{\hat{\boldsymbol{q}}}_{r}^{b}=\frac{1}{2} \hat{\boldsymbol{q}}_{r}^{b}\left(\boldsymbol{\omega}_{b}\right)_{q}+k \Delta \boldsymbol{q}
$$


以上のアルゴリズムを信号線図で表したものを Fig. 3 に示す. このアルゴリズムは単純なフィルタアルゴリズムであり, 角速 度から計算されたクォータニオンの時間微分を加速度, 地磁気 のデータを用いて補正し, それを積分した後に正規化して単位 クォータニオンの推定值を求めるというものである. 基本的に, 低周波数の姿勢変動は加速度, 地磁気のデー夕から, 高周波数の 姿勢変動はジャイロを用いて推定するという構成となっている. しかし, このアルゴリズムには以下のような問題点がある. 式 （15）において， a measure には重力を $b-$ frame 上に座標変 換した成分だけではなく，七ンサが動くことで発生する動的加 速度の成分も含まれている。このため, 動的加速度が印加され ることで姿勢データが大きな䛊差を持ってしまうのである. 実 際にセンサを水平に保った状態で大きな加速度を与えた際の姿 勢データを Fig. 4 に示す.ただし, Fig. 4 に示されているのは 推定されたクォータニオンを変換して得られたオイラー角であ る. Fig. 4 より, 加速度を加えることで最大で 20 [deg] 程度の

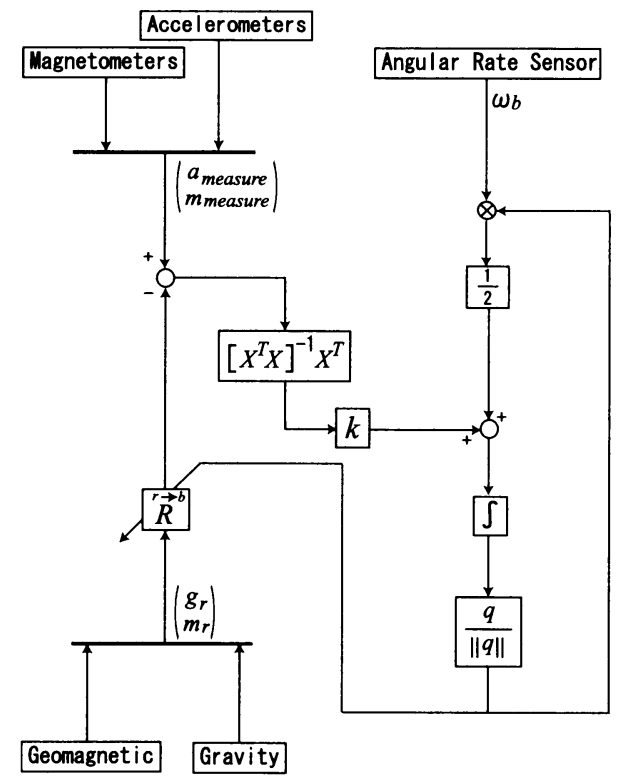

Fig. 3 Algorithm of attitude estimation

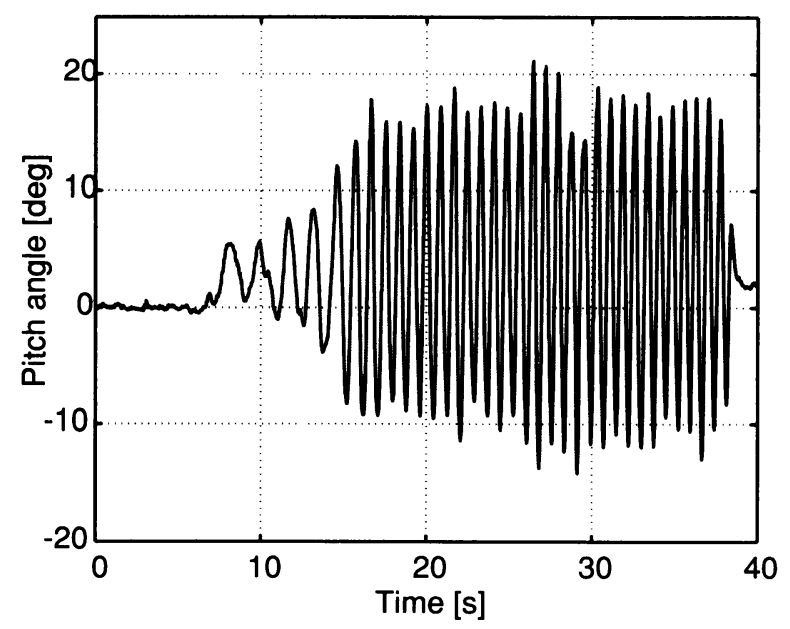

Fig. 4 Attitude error
姿勢誤差が生じていることが分かる。このような動的加速度に よる誤差は移動体に搭載するためのセンサとしては致命的であ り，なんとしても低減化する必要がある。ここで, 動的加速度 が姿勢センサシステムの観測ノイズに相当しているということ に着目すると，ノイズを含む観測信号よりシステムの真の状態 を推定することに適したカルマンフィルタを用いて姿勢推定ア ルゴリズムを構成することで誤差を低滅化できると考えられる。

\section{4. 姿勢・方位推定アルゴリズム}

\section{1 プロセスモデルの構築}

カルマンフィルタを構成するためには, システムのプロセスモ デルが必要となる，以下では，本研究で対象とするシステムの離 散時間プロセスモデルを導出する．まず，状態方程式を求める. 式（19）の右辺において $\boldsymbol{\omega}_{b}$ はジャイロセンサから得ることが できるが，ジャイロセンサや加速度センサといった慣性センサに は様々な要因による誤差があることが知られている。より精度の 高い推定を行うためにはこのような誤差も推定することが望ま しいためジャイロセンサ誤差を状態量として導入する。今, ジャ イロセンサより得られた角速度を $\boldsymbol{\omega}_{\text {measure }}=\left[\begin{array}{lll}\omega_{x} & \omega_{y} & \omega_{z}\end{array}\right]^{T}$, ジャイロセンサの誤差を $\Delta \boldsymbol{\omega}_{b}=\left[\begin{array}{lll}\delta \omega_{x} & \delta \omega_{y} & \delta \omega_{z}\end{array}\right]^{T}$ とすると， これらと $\omega_{b}$ は以下のような関係となる.

$$
\boldsymbol{\omega}_{\text {measure }}=\boldsymbol{\omega}_{b}+\Delta \boldsymbol{\omega}_{b}
$$

この式を式（19）に代入することで次式が得られる.

$$
\dot{\boldsymbol{q}}_{r}^{b}=\frac{1}{2} \boldsymbol{q}_{r}^{b}\left(\left(\boldsymbol{\omega}_{\text {measure }}\right)_{q}-\left(\Delta \boldsymbol{\omega}_{b}\right)_{q}\right)
$$

一般的に, ジャイロセンサ誤差の要因としてはバイアス誤差, ス ケールファク夕誤差, ミスアライメント誤差, ノイズ等が考え られ，これを式で表すと次式のようになる.

$$
\begin{aligned}
\Delta \boldsymbol{\omega}_{b}= & \boldsymbol{\omega}_{\text {bias }}+\left[\begin{array}{ccc}
s f_{x} & 0 & 0 \\
0 & s f_{y} & 0 \\
0 & 0 & s f_{z}
\end{array}\right] \boldsymbol{\omega}_{b} \\
& +\left[\begin{array}{ccc}
0 & m a_{x y} & m a_{x z} \\
m a_{y x} & 0 & m a_{y z} \\
m a_{z x} & m a_{z y} & 0
\end{array}\right] \boldsymbol{\omega}_{b}+\boldsymbol{\eta}
\end{aligned}
$$

上式において, 右辺第 1 項目がバイアス誤差, 第 2 項目がスケー ルファク夕誤差, 第 3 項目がミスアライメント誤差, 第 4 項目 がノイズをそれぞれ表している。この中で，スケールファク夕 誤差およびミスアライメント誤差に関してはあらかじめ計測試 験を行ったデー夕を下に補正することが可能であるため,リア ルタイムに推定する必要があるのはバイアス誤差とノイズのみ となる. また,ノイズをリアルタイムに推定するのは不可能で あるため, 今回は $\Delta \boldsymbol{\omega}_{b} \simeq \boldsymbol{\omega}_{\text {bias }}$ として, バイアス誤差の推定 のみを行う。

文献 [12] によれば，ジャイロセンサのバイアス誤差は経験的 に次のようなダイナミクスを持つことが知られている.

$$
\dot{\boldsymbol{\omega}}_{\text {bias }}=\left[\begin{array}{ccc}
-\beta_{x} & 0 & 0 \\
0 & -\beta_{y} & 0 \\
0 & 0 & -\beta_{z}
\end{array}\right] \boldsymbol{\omega}_{\text {bias }}+\boldsymbol{w}
$$


鈴木智田原

Table 3 Parameter of gyro sensor

\begin{tabular}{|l|l|}
\hline$\beta_{x}$ & 0.0033 \\
\hline$\beta_{y}$ & 0.0032 \\
\hline$\beta_{z}$ & 0.0036 \\
\hline
\end{tabular}

ただしここで, $\boldsymbol{w}=\left[\begin{array}{lll}w_{x} & w_{y} & w_{z}\end{array}\right]^{T}$ はホワイトノイズであ る. また, $\beta_{x}, \beta_{y}, \beta_{z}$ はパラメータであり,これらの值およ びホワイトノイズ $\boldsymbol{w}$ の分散は, 静置試験のデータおよび式 （25）の出力データのアラン分散 [13] が一致するように調整 し, 決定した. Table 3 に各パラメー夕の值を示す. 以上よ $\eta, \boldsymbol{x}=\left[\begin{array}{ll}\boldsymbol{q}_{r}^{b T}, & \boldsymbol{\omega}_{\text {bias }}^{T}\end{array}\right]^{T}$ を状態量としたときの状態方程式は次 式となる.

$$
\dot{\boldsymbol{x}}=\boldsymbol{f}(\boldsymbol{x})+\boldsymbol{G} \boldsymbol{w}
$$

ただし、ここで各行列は次式のようになっている.

$$
\begin{aligned}
\boldsymbol{f}(\boldsymbol{x}) & =\left[\begin{array}{c}
\frac{1}{2} \boldsymbol{q}_{r}^{b}\left(\boldsymbol{\omega}_{\text {measure }}\right)_{q}-\frac{1}{2} \boldsymbol{q}_{r}^{b}\left(\boldsymbol{\omega}_{\text {bias }}\right)_{q} \\
\boldsymbol{\beta} \boldsymbol{\omega}_{\text {bias }}
\end{array}\right] \\
\boldsymbol{G} & =\left[\begin{array}{c}
\mathbf{0}_{4 \times 3} \\
\boldsymbol{I}_{3 \times 3}
\end{array}\right] \\
\boldsymbol{\beta} & =\left[\begin{array}{ccc}
-\beta_{x} & 0 & 0 \\
0 & -\beta_{y} & 0 \\
0 & 0 & -\beta_{z}
\end{array}\right]
\end{aligned}
$$

式（26）を離散化すると式（30）のようになる．ただし， $\boldsymbol{x}_{t}$ は $t$ ステップ目の状態量であり, $\Delta t$ はサンプリングタイムである. 今回, サンプリング周波数は $50[\mathrm{~Hz}]$ であるため, $\Delta t=0.02[\mathrm{~s}]$ となっている.

$$
\boldsymbol{x}_{t+1}=\boldsymbol{x}_{t}+\boldsymbol{f}\left(\boldsymbol{x}_{t}\right) \Delta t+\boldsymbol{G} \Delta t \boldsymbol{w}
$$

ここで, 改めて $\boldsymbol{f}_{t}\left(\boldsymbol{x}_{t}\right)=\boldsymbol{x}_{t}+\boldsymbol{f}\left(\boldsymbol{x}_{t}\right) \Delta t, \boldsymbol{G}_{t}=\boldsymbol{G} \Delta t$ とおく と, 離散時間の状態方程式は次式となる.

$$
\boldsymbol{x}_{t+1}=\boldsymbol{f}_{t}\left(\boldsymbol{x}_{t}\right)+\boldsymbol{G}_{t} \boldsymbol{w}
$$

続いて, 観測方程式を求める. 機体に印加される動加速度を 含む加速度誤差 $\Delta \boldsymbol{a}=\left[\begin{array}{lll}\delta a_{x} & \delta a_{y} & \delta a_{z}\end{array}\right]^{T}$ および地磁気誤差 $\Delta \boldsymbol{m}=\left[\begin{array}{lll}\delta m_{x} & \delta m_{y} & \delta m_{z}\end{array}\right]^{T}$ を考えると加速度センサ出力およ び地磁気センサ出力は次式のように書くことができる.

$$
\begin{aligned}
\left(\boldsymbol{a}_{\text {measure }}\right)_{q} & =\boldsymbol{q}_{r}^{b *}\left(\boldsymbol{g}_{r}\right)_{q} \boldsymbol{q}_{r}^{b}+(\Delta \boldsymbol{a})_{q} \\
\left(\boldsymbol{m}_{\text {measureq }}\right)_{q} & =\boldsymbol{q}_{r}^{b *}\left(\boldsymbol{m}_{r}\right)_{q} \boldsymbol{q}_{r}^{b}+(\Delta \boldsymbol{m})_{q}
\end{aligned}
$$

ここで, $\boldsymbol{y}_{t}=\left[\begin{array}{ll}\left(\boldsymbol{a}_{\text {measure }}\right)_{q}^{T} \quad\left(\boldsymbol{m}_{\text {measure }}\right)_{q}^{T}\end{array}\right]^{T}, \boldsymbol{v}_{t}=\left[(\Delta \boldsymbol{a})_{q}^{T}\right.$ $\left.(\Delta \boldsymbol{m})_{q}^{T}\right]^{T}$ とすると, $\boldsymbol{y}_{t}$ を出力とする観測方程式は次式となる.

$$
\boldsymbol{y}_{t}=\boldsymbol{h}_{t}\left(\boldsymbol{x}_{t}\right)+\boldsymbol{v}_{t}
$$

ただし，ここで $\boldsymbol{h}_{t}\left(\boldsymbol{x}_{t}\right)$ は次式のようになっている.

$$
\boldsymbol{h}_{t}\left(\boldsymbol{x}_{t}\right)=\left[\begin{array}{c}
\boldsymbol{q}_{r}^{b *}\left(\boldsymbol{g}_{r}\right)_{q} \boldsymbol{q}_{r}^{b} \\
\boldsymbol{q}_{r}^{b *}\left(\boldsymbol{m}_{r}\right)_{q} \boldsymbol{q}_{r}^{b}
\end{array}\right]
$$

\section{2 拡張カルマンフィルタアルゴリズム}

前節において, 式 $(31)$ ，（34）のような離散時間のプロセス モデルを得ることができた。しかし，両式はともに非線形方程 式となっているため, 線形カルマンフィルタアルゴリズムをその まま適用することができない.このような場合, 式 (31)，(34) を真値に対する推定誤差に関して線形化し，推定誤差を改めて 状態量に選び, 線形カルマンフィルタを適用して誤差推定カル マンフィルタを構成する方法と, 非線形システムに線形カルマン フィルタを適用するための近似手法である拡張カルマンフィル 夕を構成するという二つの方法がある [14] が, 今回は後者を選 択した．以下では，拡張カルマンフィルタアルゴリズムについて 説明を行う。今, 式 $(31),(34)$ のシステムに関して, $t$ ステッ プ目における $\boldsymbol{x}_{t}$ の濾波推定值を $\hat{\boldsymbol{x}}_{t / t}$, 予測推定値を $\hat{\boldsymbol{x}}_{t / t-1}$ としたとき，行列 $\boldsymbol{F}_{t}$ および $\boldsymbol{H}_{t}$ を次式のように定義する.

$$
\boldsymbol{F}_{t}=\left(\frac{\partial \boldsymbol{f}_{t}}{\partial \boldsymbol{x}_{t}}\right)_{\boldsymbol{x}_{t}=\hat{\boldsymbol{x}}_{t / t}} \quad \boldsymbol{H}_{t}=\left(\frac{\partial \boldsymbol{h}_{t}}{\partial \boldsymbol{x}_{t}}\right)_{\boldsymbol{x}_{t}=\hat{\boldsymbol{x}}_{t / t-1}}
$$

以上のように定義された行列を用いた拡張カルマンフィルタア ルゴリズムは以下に示す式で与えられる.

$$
\begin{aligned}
\boldsymbol{K}_{t} & =\boldsymbol{P}_{t / t-1} \boldsymbol{H}_{t}^{T}\left[\boldsymbol{H}_{t} \boldsymbol{P}_{t / t-1} \boldsymbol{H}_{t}^{T}+\boldsymbol{R}_{t}\right]^{-1} \\
\hat{\boldsymbol{x}}_{t / t} & =\hat{\boldsymbol{x}}_{t / t-1}+\boldsymbol{K}_{t}\left[\boldsymbol{y}_{t}-\boldsymbol{h}_{t}\left(\hat{\boldsymbol{x}}_{t / t-1}\right)\right] \\
\boldsymbol{P}_{t / t} & =\boldsymbol{P}_{t / t-1}-\boldsymbol{K}_{t} \boldsymbol{H}_{t} \boldsymbol{P}_{t / t-1} \\
\hat{\boldsymbol{x}}_{t+1 / t} & =\boldsymbol{f}_{t}\left(\hat{\boldsymbol{x}}_{t / t}\right) \\
\boldsymbol{P}_{t+1 / t} & =\boldsymbol{F}_{t} \boldsymbol{P}_{t / t} \boldsymbol{F}_{t}^{T}+\boldsymbol{G}_{t} \boldsymbol{Q}_{t} \boldsymbol{G}_{t}^{T}
\end{aligned}
$$

ただしここで, 式中の $\boldsymbol{K}_{t}$ はカルマンゲイン， $\boldsymbol{P}_{t / t}$ および $\boldsymbol{P}_{t / t-1}$ は推定誤差の共分散行列, $\boldsymbol{Q}_{t}$ はシステムノイズの共分 散行列, $\boldsymbol{R}_{t}$ は観測ノイズの共分散行列をそれぞれ表している. 上記の式 $(37) \sim(41)$ のアルゴリズムは, 得られた観測值を用 いて推定值を滤波する部分と, 次ステップの推定值を予測する 部分の二つから構成されており，それぞれ式 $(37) \sim(39)$ が前 者に, 式 (40)，（41）が後者に当たる.また，前者を観測更新， 後者を時間更新と呼ぶこともある. 以上のように与えられた式 を順に計算することで, $\mathrm{t}$ ステップ目における $\boldsymbol{x}_{t}$ の最も確から しい濾波推定值 $\hat{\boldsymbol{x}}_{t / t}$ を得ることができる.

\section{5. シミュレーションおよび実験}

\section{1 シミュレーション}

今回の主目的である動的加速度環境下における姿勢誤差の低 減化を実現するためには, 観測ノイズの共分散行列 $\boldsymbol{R}_{t}$ の決め 方が重要になる。ここでは， $\boldsymbol{R}_{t}$ の值をシミュレーションによ り決定する.まず，動的加速度による誤差が少なくなるように $\boldsymbol{R}_{t}$ の值を決定した.このときの值を $\boldsymbol{R}_{1}$ とする. Fig. 5 に $\boldsymbol{R}_{1}$ によるシミュレーション結果を示す. Fig. 5 (a) が姿勢を変動さ せたとき, Fig. 5 (b) がセンサを水平に保った状態で, Fig. 1 の $b$ - frame 上 $X_{b}$ 軸方向, すなわちピッチ角度に大きな誤差 が生じやすい方向に正弦波状の動的加速度を印加したときのシ ミュレーション結果である. また, それぞれ破線が従来のアル 


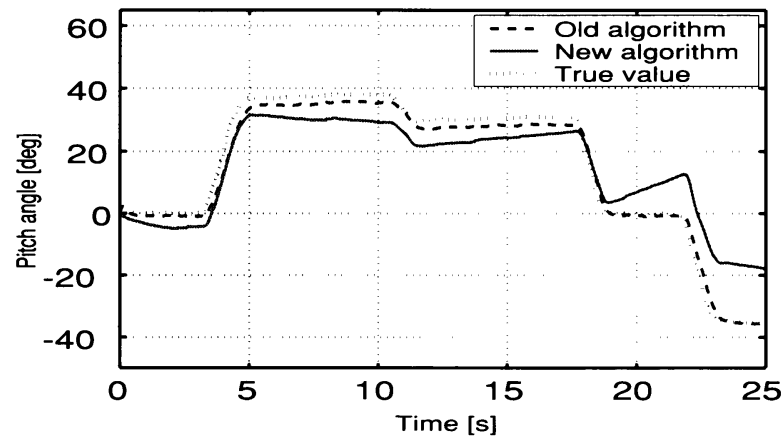

(a) In the rotation

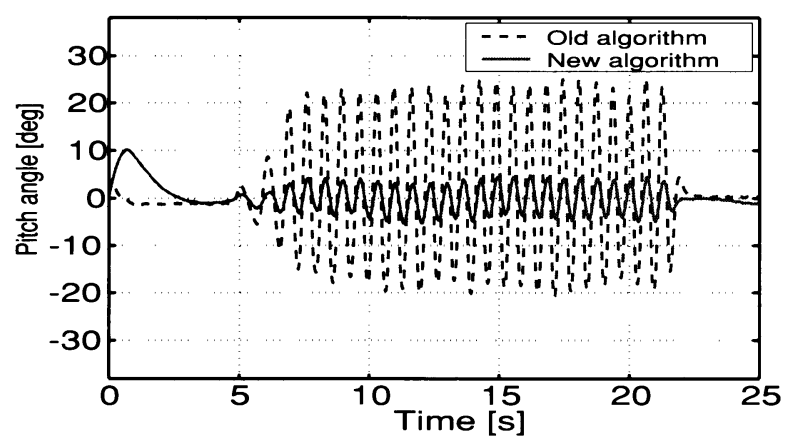

(b) In the linear acceleration

Fig. 5 Simulation result of $\boldsymbol{R}_{1}$

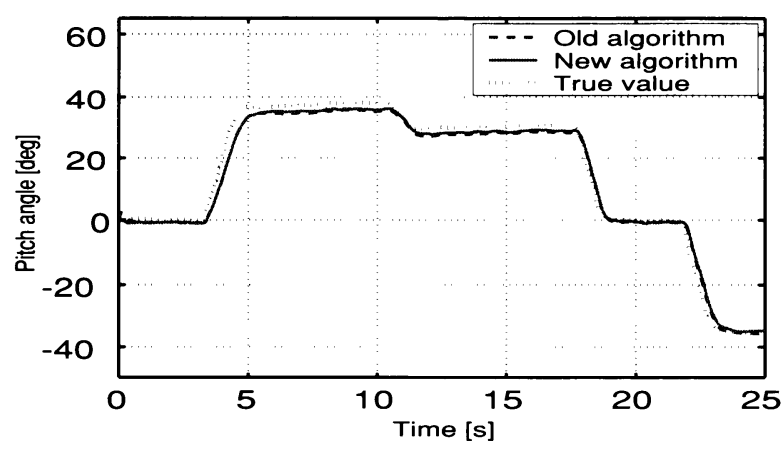

(a) In the rotation

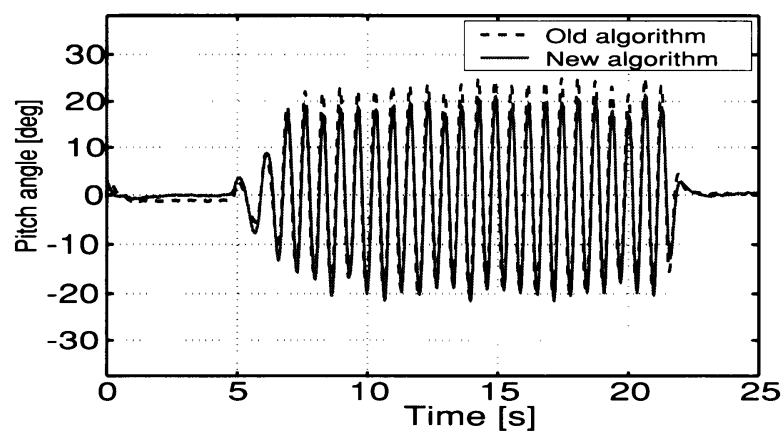

(b) In the linear acceleration

Fig. 6 Simulation result of $\boldsymbol{R}_{2}$

ゴリズムによる結果，実線が拡張カルマンフィル夕による結果， 点線がその際の真の姿勢值である. Fig. 5 より， $\boldsymbol{R}_{1}$ を用いると 動的加速度による誤差は低減化するが, 姿勢の追従が極端に遅 くなってしまうことが分かる。一方, 姿勢の追従を十分に速く なるような $\boldsymbol{R}_{t}$ の值を $\boldsymbol{R}_{2}$ として， $\boldsymbol{R}_{2}$ による結果を Fig. 6 に

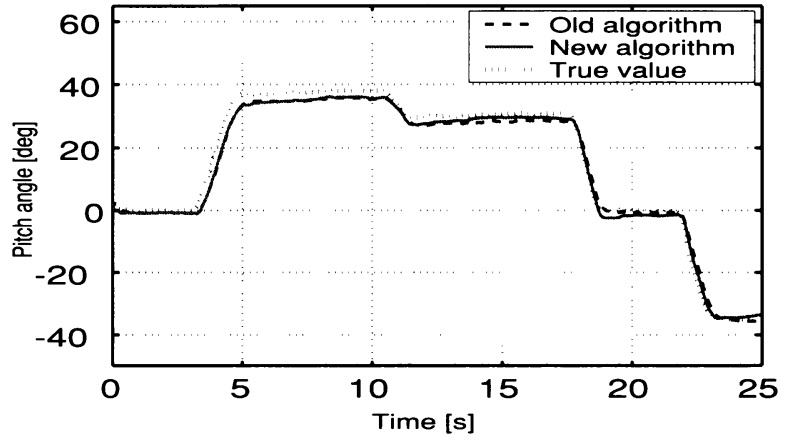

(a) In the rotation

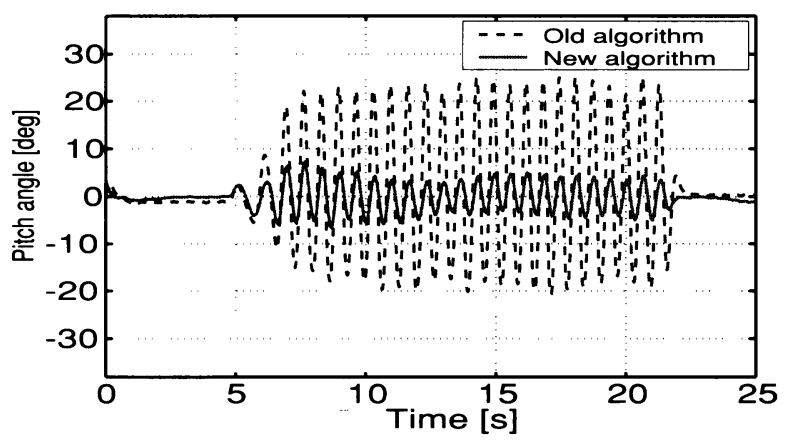

(b) In the linear acceleration

Fig. 7 Simulation result of eq. (39), (40)

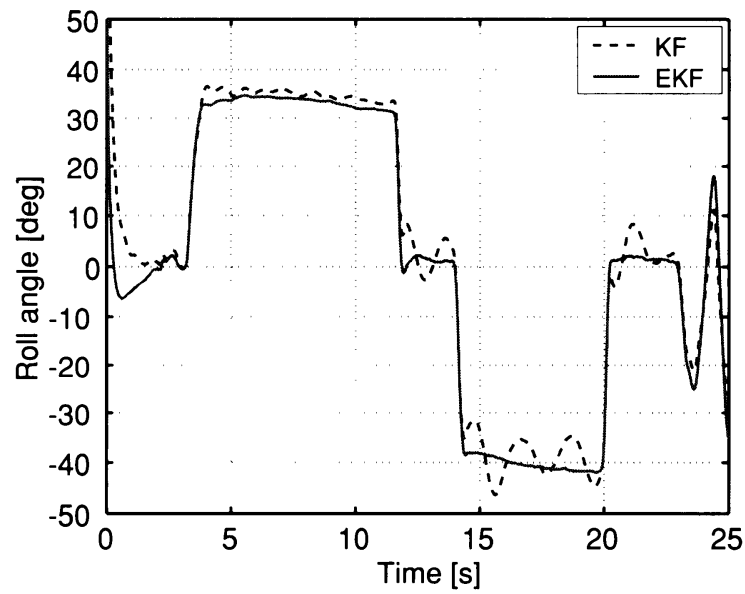

Fig. 8 Simulation result of roll angle

示す. Fig. 6 より $\boldsymbol{R}_{2}$ を用いると姿勢の追従は良くなるが, 動 的加速度誤差が低減化できないことが分かる，そこで，上述の $\boldsymbol{R}_{1}, \boldsymbol{R}_{2}$ を用いて $\boldsymbol{R}_{t}$ を次式のような関数とした. ただし， $\boldsymbol{K}_{R}$ は適当なゲインである.また， $T$ に関してはシミュレーション を繰り返すことによって適当な值を決定した。 今回， $T$ の值は $11[\mathrm{~s}]$ となっている.

$$
\begin{array}{lr}
\boldsymbol{R}_{t}=\boldsymbol{R}_{2}+\boldsymbol{K}_{R}\left(\boldsymbol{R}_{1}-\boldsymbol{R}_{2}\right) t & 0 \leq t<T \\
\boldsymbol{R}_{t}=\boldsymbol{R}_{1} & t \geq T
\end{array}
$$

このときのシミュレーション結果を Fig. 7 に示す．以上のよ うな $\boldsymbol{R}_{t}$ を用いることで，姿勢の追従が速く，動的加速度によ る䛊差は低減化できるような結果を得ることができた。続いて Fig. 8１0 に線形誤差推定カルマンフィルタ（KF）と今回用 


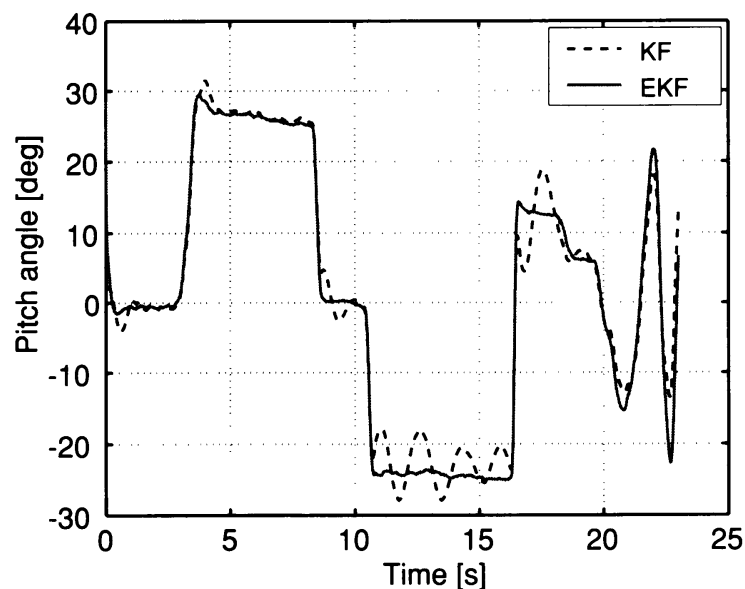

Fig. 9 Simulation result of pitch angle

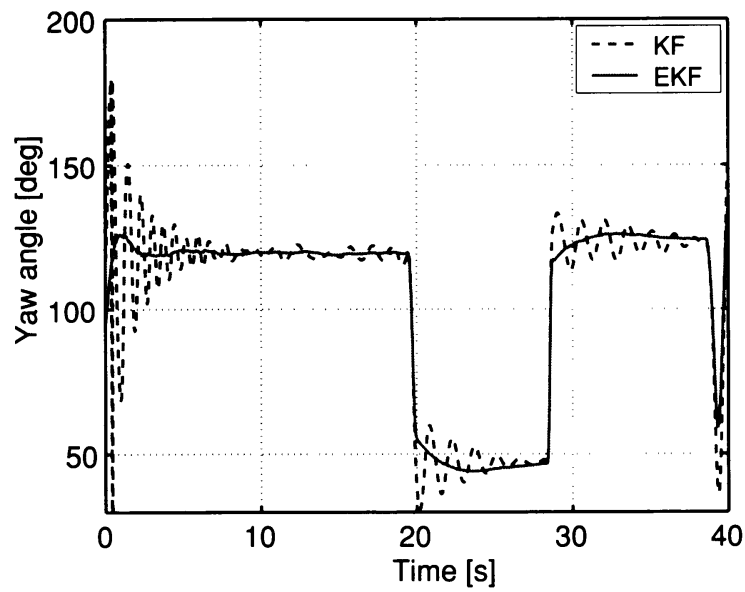

Fig. 10 Simulation result of yaw angle

いた拡張カルマンフィルタ（EKF）の比較を示す．KF の結果 は EKF と比べて振動的になってしまっていることが分かる.こ れは, 式 (34) の観測方程式に含まれる座標変換の非線形性を KF では十分に考慮できていないためであると考えられる.

\section{2 実験}

従来のアルゴリズムおよび拡張カルマンフィルタアルゴリズ ムをマイクロコンピュータ上に実装し，リアルタイムで姿勢・ 方位推定を行った結果を Fig. 11〜14 に示す. 比較対象とし て，Crossbow 社製の高精度姿勢センサAHRS400を選択した。 この AHRS400 は移動体に搭載することを目的とした姿勢七 ンサであり，動的加速度を印加しても姿勢誤差が生じにくいと いう特徴を持っている. しかし，その重量は約 $700[\mathrm{~g}]$ であり MARG センサの 10 倍以上となっている. AHRS400 の全体像 を Fig. 15 に示す。本来であれば AHRS400 と MARG センサ をともに小型無人へリコプタ上のマウントに搭載し，飛行しつ つ姿勢データの比較を行うことが望ましいが, AHRS400の重 量の関係上それは難しいため，今回は両センサを同一マウント 上に搭載した状態で，そのマウントを地上で動かすという試験 方法をとった。ちなみに，比較を行いやすくするために，得られ たクォータニオン推定值をオイラー角に変換した後にプロット している. Fig. 11 がロール角度, Fig. 12 がピッチ角度, Fig. 13

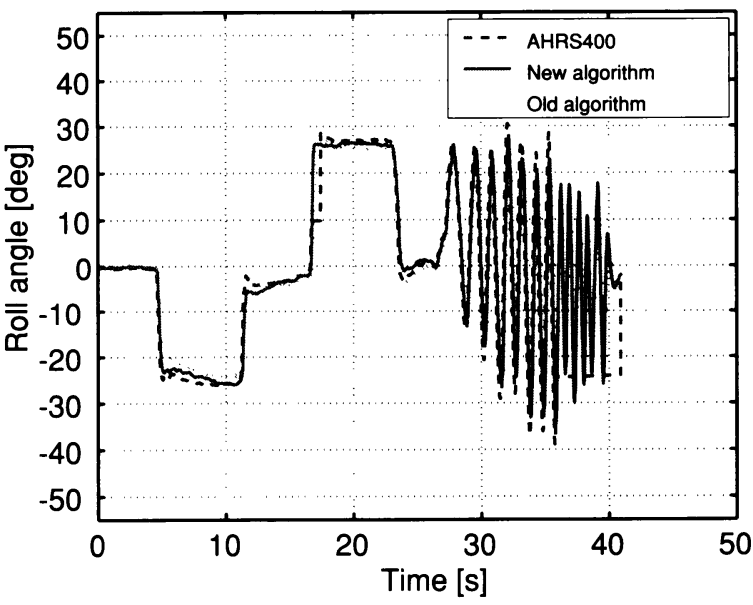

Fig. 11 Experiment result of roll angle

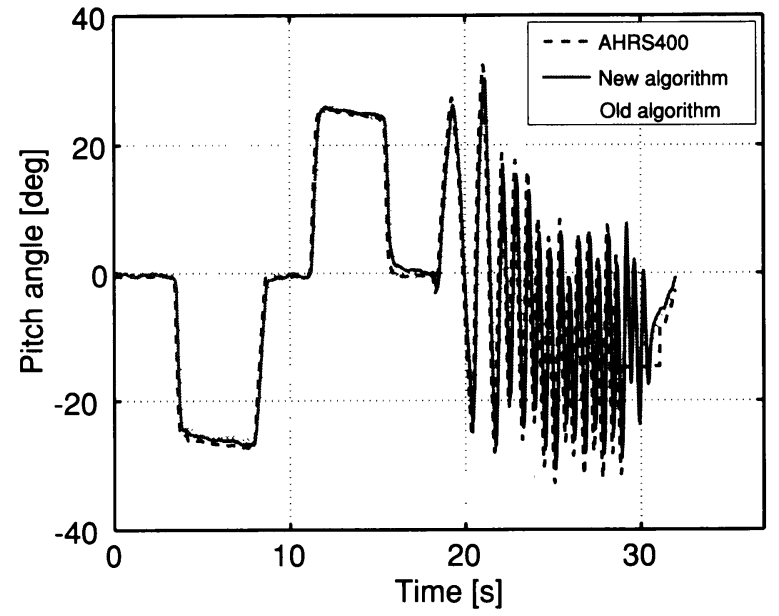

Fig. 12 Experiment result of pitch angle

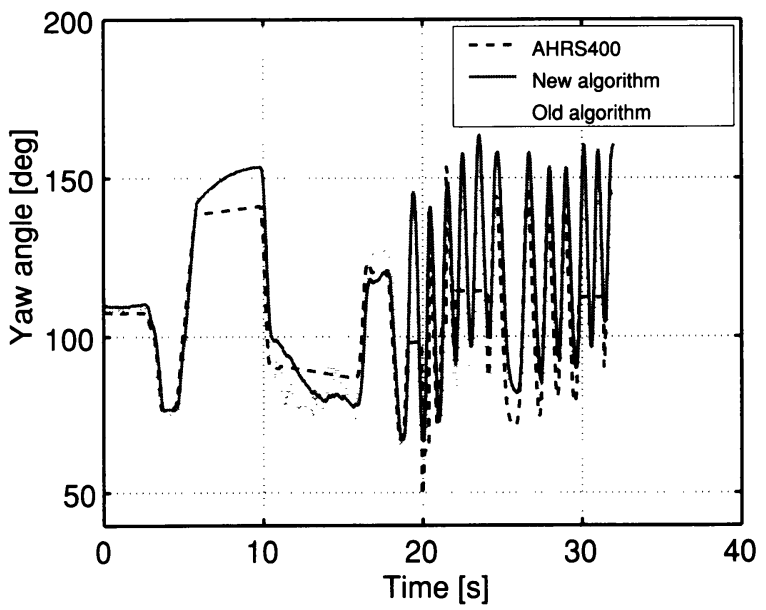

Fig. 13 Experiment result of yaw angle

がヨー角度のデータをそれぞれ示している．また，Fig. 14 には センサを水平に保った状態で，シミュレーションと同様に Fig. 1 の $b$ - frame 上 $X_{b}$ 軸方向に正弦波状の動的加速度を印加した ときのピッチ角度のデータを示している．このとき，小型無人 ヘリコプタに搭載することを想定し, Fig. 11〜13 に関しては小 


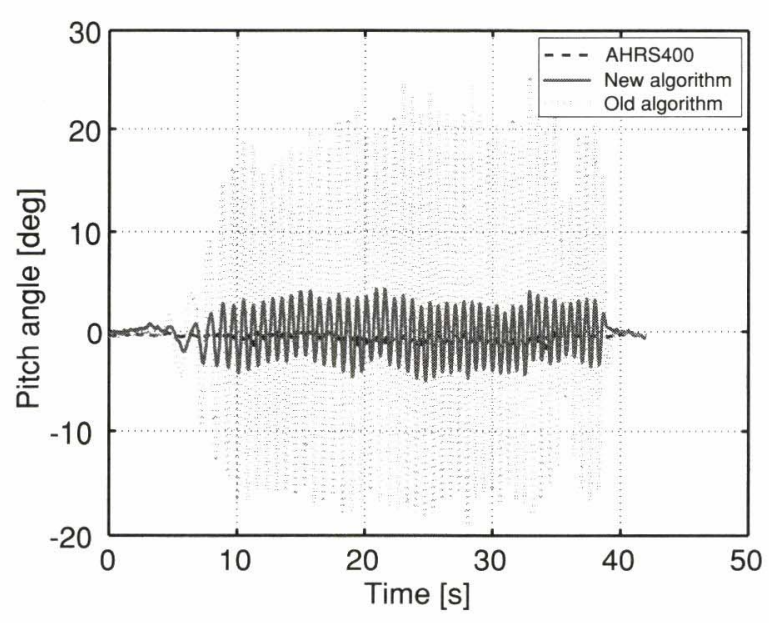

Fig. 14 Experiment in the linear acceleration

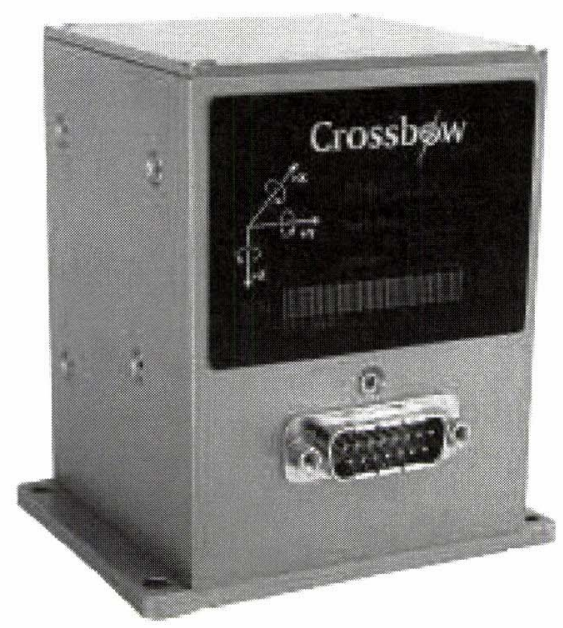

Fig. 15 Overview of AHRS400 [10]

Table 4 RMS value of acceleration

\begin{tabular}{|c|c|}
\hline Condition & RMS of acceleration $\left[\mathrm{m} / \mathrm{s}^{2}\right]$ \\
\hline Hover & 0.5479 \\
\hline Circular flight & 1.0511 \\
\hline Experiment & 2.5823 \\
\hline
\end{tabular}

型無人ヘリコプタの運動の際に発生する角速度を大きく上回る ように最大 $250[\mathrm{deg} / \mathrm{s}]$ の角速度環境下に扔いて試験を行ってお り, Fig. 14 に関しては, 小型無人ヘリコプタの飛行中に加わる 加速度と比較して十分大きな加速度を印加している. Table 4 に小型無人へリコプタの各飛行状態および今回の試験における 加速度の RMS 值を示している. それぞれ,「Hover」がホバリ ング飛行中, 「Circular flight」が比較的大きな加速度が印加さ れる旋回飛行中, 「Experiment」がFig. 14 に示す試験中の值で ある. Fig. 11〜13より，おおむね AHRS400 と MARG センサ のデータは一致しており, 正確な推定が行えているということ が分かる.しかし，Fig. 13の6〜16 秒付近において AHRS400 と比較して提案手法および従来手法のデータが誤差を持ってい ることが分かる。これは磁気外乱の影響であると考えられ，小 型無人へリコプタの飛行する屋外では特に大きな問題ではない が, 今後, このような磁気外乱の影響も低減化するように改良
する必要があると考えられる，また，AHRS400のデータが一定 值となっている箇所がいくつかあるが,これはAHRS400 は角 速度が $200[\mathrm{deg} / \mathrm{s}]$ 以下でしか姿勢の推定を行えず, $200[\mathrm{deg} / \mathrm{s}]$ 以上の角速度を与えると姿勢の推定が停止してしまうためであ る.これに対して, MARG センサでは $200[\mathrm{deg} / \mathrm{s}]$ 以上の角速 度を与えた際も推定を行うことができている。, 一方, 動的加速 度を印加した際のデータに着目すると, 提案手法を用いた場合, 加速度を印加しても姿勢誤差を十分に低減化できており, 仕様 を十分に満たしているということが分かる。

\section{6. おわりに}

本稿では, 先行研究において開発された MARGセンサの問題 点である動的加速度環境下での姿勢誤差を低減化するために, 慣 性センサのバイアス推定を含む拡張カルマンフィルタを姿勢推定 アルゴリズムとして適用し，加速度環境下での精度の高い姿勢. 方位推定を実現した。今後は, 現在平行して開発中の MARG センサと安価 GPS を用いた複合航法アルゴリズムと組み合わ せることによって, 小型・軽量·安価の航法ユニットを開発す ることを目指す。また，MARGセンサから出力されるクォータ ニオンを直接用いた小型へリコプタの姿勢制御系の構築を行う 予定である.

\section{参 考 文 献}

[1] D.H. Shim, et al.: "A Flight Control system for Aerial Robots: Algorithms and Experiments," Control Engineering Practice vol.11, Issue 12, pp.1389-1400, 2003.

[ 2 ] H. Stone and K.C. Wong: "Preliminary Design of a TandemWing Tail-Sitter UAV Using Multi-Disciplinary Design Optimisation," International Aerospace Congress, Sydney, pp.707720, February 1997.

[3] 辛振玉, 藤原大悟, 羽沢健作, 野波健蔵：“ラジコンヘリコプタの姿 勢制御・ホバリング制御”, 日本機械学会論文集, vol.68, no.675, C 編, pp.3284-3291, 2002.

[4] 藤原大悟, 辛振玉, 羽沢健作, 野波健蔵：“自律小形無人へリコプタの H œホバリング制御および誘導制御”, 日本機械学会論文集, vol.70, no.694, C 編, pp.1708-1714, 2004.

[5] 羽沢健作, 辛振玉, 藤原大悟, 五十嵐一弘, D. Fernando, 野波健蔵： “ホビー用小形無人ヘリコプタの自律制御（実験的同定に基づくモデ リングと自律制御実験)”, 日本機械学会論文集, vol.70, no.691, C 編, pp.720-727, 2004.

[6] J. Shin: "Autonomous Control and Compact Sensor Development of Small-Scale Helicopter," Ph.D Thesis of Chiba University, 2005.

[ 7 ] 鈴木智, 辛振玉, 田原誠, 小出義郎, 中澤大輔, 野波健蔵: “ホビー クラス約 $5 \mathrm{~kg}$ 無人ヘリコプタの解析的モデリングと自律ホバリング 制御”, 日本機械学会論文集, vol.73, no.726, C 編, pp.562-569, 2007.

[8] J.L. Marins, et al.: "An Extended Kalman Filter for Quaternion-Based Orientation Estimation Using MARG Sensors," Proc. of IROS 2001, pp.2003-2011, 2001.

[9] A.M. Sabatini: "Quaternion-Based Extended Kalman Filter for Determining Orientation by Inertial and Magnetic Sensing," IEEE Trans. A.M.Biomedical Engineering, vol.53, Issue7, pp.1346-1356, July, 2006.

[10] http://www.xbow.jp/

[11] 田島洋：マルチボデイダイナミクス一 3 次元運動方程式の立て方. 東 京電機大学出版局, 2006.

[12] R.M. Rogers: Applied Mathematics in Integrated Navigation System. Second Edition, AIAA Education Series, 2003.

[13] D.W. Allan: "Time and Frequency (Time-Domain) Characteri- 


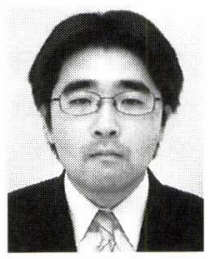

鈴木 智 (Satoshi Suzuki)

2006 年千葉大学大学院自然科学研究科博士前期課 程修了. 2008 年同大学大学院自然科学研究科博士 後期課程修了。同年 4 月より日本学術振興会特別 研究員, 現在に至る. 小型無人ヘリコプタの自律制 御および小型姿勢センサに関する研究に従事（工学 博士).

(日本ロボット学会正会員)

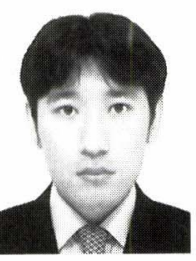

中澤大輔（Daisuke Nakazawa）

2005 年千葉大学工学部卒業. 2007 年同大学大学院 自然科学研究科博士前期課程修了. 同年 4 月に同 大学大学院工学研究科人工システム科学専攻博士後 期課程に入学し, 現在に至る.小型無人へリコプタ の自律制御に関する研究に従事.

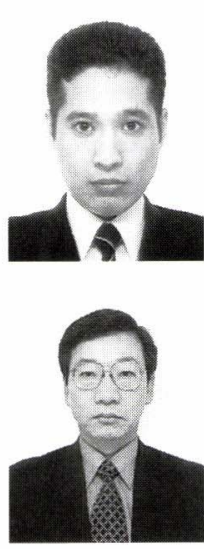

田原 誠 (Makoto Tawara)

2004 年大阪府立大学工学部卒業. 同年 4 月ヒロボー 株式会社入社，現在に至る。小型無人ヘリコプタの 自律制御掞よび小型姿勢センサに関する研究に従事. ホイールの制御, 制御尤用などの研究に従事、日本機械学会, 計湘白 動制御学会, システム制御情報学会, 日本フルードパワーシステム学 会, IEEE, ASME, AHS 等の会員.

(日本ロボット学会正会員) 